\title{
NOTES ON THE MOSQUITOS OF MADAGASCAR, MAURITIUS AND RÉUNION.
}

\author{
By F. W. Edwards,
}

(Published by permission of the Trustees of the British Museum.)

Through the kindness of Mons. E. Séguy, of the Muséum d'Histoire Naturelle, Paris, I have recently been enabled to examine a considerable number of mosquitos from Madagascar and the neighbouring French islands, including the types or cotypes of all the species described from Madagascar by Ventrillon. As the examination of this material has disclosed the existence of several species hitherto unrecorded from these islands, as well as some new synonymy, it has been thought desirable to record the results at once. In the following pages all the species of mosquitos hitherto known from this region are dealt with. The total number is only 28 , as compared with about 180 in the African fauna, so that it is highly probable that further collecting would produce many others.

Anopheles mauritianus, Daruchy de Grandpré \& d'Emmerez de Charmoy.

Ambatofanghera and Ambohipomana (Bouet, 1905); Tananarive (Neiret and Ventrillon, 1904 ; Bouet 1905).

The commonest Anopheles in Mauritius, according to d'Emmerez.

Anopheles maculipalpis, Giles.

Occurs rarely in Mauritius (d'Emmerez de Charmoy).

Anopheles squamosus, Theobald.

Cellia tananariviensis, Ventrillon.

According to Ventrillon this is by far the commonest Anopheles in Madagascar and his statement is certainly borne out by its abundance in the collections which I have examined. No constant difference was observable between Madagascan and African specimens.

Anopheles pharoensis, Theobald.

A single specimen, much damaged but undoubtedly this species, from Tananarive (Ventrillon, 1905).

Anopheles funestus, Giles.

Four females from Moratsiazo, Lac Itasy (Bouet, 1904).

Anopheles marshalli, Theo.

Females from Tananarive (Neiret, 1904, and Ventrillon, 1905) and Ambohipomana (Bouet, 1905).

Anopheles transvaalensis, Carter.

Two females from Tananarive (Bouet, 1905). 
Anopheles costalis (Loew) Theobald.

Females from Mauritius, where, according to d'Emmerez, the species is common, are in the Paris Museum.

\section{Aedes (Stegomyia) albopicta, Skuse.}

Stegomyia lamberti, Ventrillon, Bull. Mus. Paris, x, p. 552 (1904) and Arch. Parasit. ix, p. 441 (1905).

Stegomyia scutellaris, Theobald et auct. (nec Walker).

Ventrillon's types included both sexes, so that the identification of $S$. lamberti is beyond doubt, notwithstanding the fact that Ventrillon states that the female claws are toothed, whereas in all specimens I have examined they are simple. Either Ventrillon made a mistake, or the species is variable in this respect, which is not unlikely.

This species also occurs at Réunion as shown by specimens in the Paris Museum, collected at St. Denis, v-vi, 1913 (Surcouf). It has been recorded from Mauritius, where it is said to be very common (d'Emmerez de Charmoy). It is surprising that it does not seem to occur on the African mainland, since it has such a wide range throughout the Oriental region.

Aëdes (Stegomyia) argenteus, Poiret (fasciata, Fb.).

Culex insatiabilis, Bigot, Ann. Soc. Ent. France, (3) vii, p. 118 (1859).

Bigot's description and figure can apparently only apply to this species, which is common on the islands, especially near the coast (d'Emmerez de Charmoy).

\section{Aëdes (Skusea) cartroni, Ventrillon.}

Stegomyia cartroni, Ventrillon, Bull. Mus. Paris, xii, p. 143 (1906).

This species, which I had not previously seen, evidently belongs to the sub-genus Skusea, although the male is unfortunately unknown. It is very close to $S$. pembaensis, the type of the subgenus, so close indeed that it may eventually prove to be a variety only. However in all the examples of $S$. pembaensis received at the British Museum the abdomen is unbanded dorsally, and the scutellar scales are black, while in the few specimens of $S$. cartroni sent the abdominal segments have narrow pale basal bands, and the few remaining scutellar scales are white.

\section{Aëdes (Ochlerotatus) nigeriensis, Theobald.}

Culex fowleri, d'Emmerez de Charmoy, Ann. Trop. Med. ii, p. 258 (1908).

Mr. H. F. Carter informs me that he has examined a male of $C$. fowleri from Mauritius, and established its identity with $O$. nigeriensis, which was already suggested by the author's allusion to the two pale spots on the sixth abdominal tergite of the female.

A female in the Paris Museum from Madagascar may be either this species or o. fryeri, Theo. 
Orthopodomyia arboricollis, d'Emmerez de Charmoy.

Culex arboricollis, d'Emmerez de Charmoy, Ann. Trop. Med. ii, p. 257 (1908).

Newsteadina ar?oricollis, Theobald, Ann. Trop. Med. ii, p. 297 (1909).

This species, which is so far only known from Mauritius, is a typical Orthopodomyia. I have examined the types in the Liverpool School of Tropical Medicine and find that the female has the very short fourth tarsal joint on the front and middle legs, characteristic of this genus, while the male hypopygium is very similar to that of the other species.

Taeniorhynchus (Mansonioides) uniformis, Theobald.

Females of this species in quite recognisable condition from Ambatofanghera (Bouet, 1905). Other specimens. probably of $T$. (M.) uniformis, were from Morouslava (Dr. Petit, 1901).

Taeniorhynchus (Coquillettidia) flavus, Ventrillon.

Culex favus, Ventrillon (nec Motschulsky), Bull. Mus. Paris, x, p. 550 (1904).

Culex grandidieri, Blanchard, Les Moustiques, p. 627 (1905).

Several females, including cotypes of Ventrillon, from Tananarive (Dr. Ventrillon, 1905).

This is very close to the African T. fuscopennatus, of which it may be a mere local form; the hypopygia are very similar, as is shown by a drawing taken from Ventrillon's male cotype which M. Séguy kindly sent me; this indicates the clasper as having a rather different shape. T. flavus, however, in all the examples $\mathrm{I}$ have seen, is readily distinguishable by the coloration of the scales on the wing, particularly the apical half. The costa is yellow, with a line of black scales on the outer margin on its basal two-thirds; subcostal and first longitudinal veins predominantly yellow, apically entirely so ; stems of fork-cells and tips of veins round wing-tip yellow; remaining veins and fringe mainly black. This description is considerably at variance with that of Ventrillon, but an examination of the cotypes showed that his was inaccurate.

T. fuscopennatus differs in having the dark and light wing-scales fairly evenly mixed, and also in having the integument of the thorax blackish or dark brown, that of $T$. flavus being light brown.

$T$. aureus, Edw., has an almost greater resemblance even than $T$. fuscopennatus, but it again has a rather differently shaped clasper, and has the costa entirely yellow.

I have adopted the name flavus rather than grandidieri, because the Culex flavus of Motschulsky is probably an Aëles, Ventrillon's later flavus being therefore valid in the genus Taeniorhynchus.

\section{Culex ventrilloni, sp. $\mathrm{n}$.}

‥ Head scales narrow, blackish ; a rim round the eyes and a longitudinal band down the middle pale golden. Proboscis with a distinct yellow median ring, broader below than above. Palpi one-fourth as long as the proboscis, black, with some white scales about the middle. Thorax blackish brown, bristles dark. Prothoracic lobes with a few narrow golden scales; mesonotum with golden and dark brown scales, the former occurring in an indefinite line in the middle and in some large 
rather irregular patches on each side on the front half. Scutellum pale, with narrow pale golden scales. Pleurae with four or five small patches of pale ochreous flat scales. Abdomen dark brown, tergites with white basal lateral patches and ochreous basal bands, which are broadest in the middle; sternites with dark apical bands. Legs black; all the femora black to the base above, ochreous beneath on the basal half. Femora and tibiae all with conspicuous whitish tips, no scattered pale scales. Tarsal joints conspicuously ringed with ochreous at the base only; the rings on the last two joints very narrow. Claws simple; empodia large, nearly as long as the claws. Wings with brown scales, those in the lateral series linear. First fork-cell more than twice as long as its stem, its base nearer the base of the wing than that of the second. Cross-veins separated by rather more than the length of the posterior.

Length, $6 \mathrm{~mm}$.

Madagascar : Tananarive, 1904, 1 ( (Dr. Neiret) and 1905, 2 q (Dr. Ventrillon). Type in the Paris Museum; paratype in the British Museum.

This species is noteworthy for the ornamentation of the head, the basally ringed tarsal joints, and the large empodia. It has no near ally among the described African and Oriental species, and in the absence of the male it is impossible to say in what subgenus it should be placed. Possibly it may be a Lutzia.

\section{Culex annulitarsis, Macquart.}

The brief description of Macquart will not apply to any known species. It was referred by Theobald to the synonymy of Stegomyia fasciata, but Macquart's description of the legs (hind tibiae with a broad white ring before the tip; hind metatarsi white, with a narrow black ring) makes the reason for this far from obvious.

Culex (Lutzia) tigripes, Grandpré \& Charmoy.

Tamatave (Jaillet). Described from Mauritius.

\section{Gulex (Culex) quasigelidus, Theobald.}

\section{Pseudoheptaphlebomyia madagascariensis, Ventrillon.}

This synonymy, previously given by me, can be confirmed from an examination of the types, although Ventrillon's description does not agree. Additional specimens are from Ambohipomana (Bouet, 1905) and Tananarive (Waterlot, 1916).

Culex (Culex) giganteus, Ventrillon.

Culex giganteus, Ventrillon, Bull. Mus. Paris, xii, p. 100 (1906).

Culex neireti, Ventrillon, Bull. Mus. Paris, xii, p. 103 (1906).

The original description of $C$. giganteus and $C$. neireti are very similar, except as regards the size given and the markings of the thorax. Study of the types shows that the insects are actually the same, the differences in the description being due to inaccurate observation. In particular, Ventrillon's measurement of $10 \mathrm{~mm}$. body length for C. giganteus is a considerable exaggeration, the actual length being only about $6 \mathrm{~mm}$., excluding the proboscis. Additional specimens are from Ambatofanghera and Ambohipomana (Bouet, 1905).

The species is a close ally of the African C. annulioris, Theo., differing chiefly in the greater extension of the yellow markings of the abdomen; and in some small details of the structure of the male hypopygium, notably the shorter and stouter 
basal arms of the tenth sternites. Perhaps the single specimen of $C$. annulioris recorded by d'Emmerez de Charmoy (Ann. Trop. Med. ii, p. 260) may have been C. giganteus.

\section{Culex (Culex) sitiens, Wied.}

Culex ronaldi, d'Emmerez de Charmoy, Ann. Trop. Med. ii, p. 259 (1908).

Recorded from Mauritius, but not from Madagascar, where however it is very likely to occur, since it has a wide distribution from East Africa to Australia.

Gulex (Culex) univittatus, Theobald.

Heptaphlebomyia montforti, Ventrillon, Arch. Parasit. ix, p. 448 (1905).

My previous statement as to the identity of $C$. univittatus and $H$. montforti is confirmed by an examination of the male hypopygium of one of Ventrillon's specimens.

\section{Culex (Culex) pipiens, L.}

Tananarive (Neiret, 1904 ; Ventrillon, 1905).

This record forms a further notable extension of the known range of this species, which until recently was thought to be confined to the temperate regions of the northern hemisphere. It is now known also from South and East Africa and from the Argentine.

Culex (Culex) ? laurenti, Newstead.

Some female specimens from Tananarive (Neiret, 1904) are perhaps this species, though it is possible that they may belong to the variety of C. pipiens with an unbanded abdomen, which is known from East Africa and from the Mediterranean region.

\section{Culex (Culex) fatigans, Wied.}

Culex cartroni, Ventrillon, Bull. Mus. Paris, xi, p. 429 (1905).

Culex anxifer, Bigot, Ann. Soc. Ent. France, (3) vii, p. 117 (1859).

The hypopygium of Ventrillon's type male was mounted and proved it to be this species. Other specimens from Réunion (Surcouf). The commonest mosquito in Mauritius (d'Emmerez de Charmoy).

Bigot's description of $C$. anxifer is unrecognisable, and he had no type, but Blanchard has referred his name to the synonymy of $C$. fatigans, and there seems no sufficient reason to dispute this.

Culex (Culex) argenteopunctatus, Ventrillon.

Heptaphlebomyia argenteopunctata, Ventrillon, Arch. Parasit. ix, p. 446 (1905).

Heptaphlebomyia kingi, Theobald, Ann. Trop. Med. vii, p. 601 (1913).

A number of females, all in poor condition, some barely recognisable, from Tananarive (Ventrillon, Bouet, Guérin Méneville, Waterlot).

A male in the British Museum named by Ventrillon lacks the abdomen, but fortunately there is another, in perfect condition, from the Gold Coast (Dr. A. Ingram). I have mounted the hypopygium of this and find that it is a true Culex bearing a rather considerable resemblance to $C$. decens, Theo. The two silvery spots on the thorax are remarkable and absolutely diagnostic, being comparable only with certain species of Aëdes, e.g., punctothoracis, Theo. 


\section{Uranotaenia neireti, sp. $\mathbf{n}$.}

o Head scales and integument blackish, a spot of pale blue in the middle in front, and another on each side at the eye-margin. Proboscis slightly longer than the abdomen, slightly swollen at the tip. Thorax brown, lower half of pleurae somewhat lighter. Prothoracic lobes with light blue scales; proepimera bare, lower half blackish. Mesonotum with narrow dark brown scales, those on the scutellum flat; no lateral line of flat scales. A spot of pale blue scales in middle of pleurae, and a few more scattered on sternopleura ; integument darker on each side of the blue spot. Abdomen dark brown above, lighter brown beneath. Legs dark brown; coxae and bases of femora ochreous; tip of third and whole of fourth tarsal joint of hind legs whitish; fifth darker. Tarsi and claws normal. Wings with brown scales only, those towards the apex rather narrowly spatulate. Upper fork-cell more than half as long as its stem.

Length, $3 \mathrm{~mm}$.

Madagascar : $1 \delta 1 \%$ (Dr. Ventrillon), without exact locality, labelled "Ficalbia neireti. Type : Ventr." Type $\sigma^{\star}$ in the Paris Museum. The female and a second male from Tananarive (Ventrillon, 1905) have the blue scales replaced by greyish white, probably owing to fading.

Eretmopodites quinquevittatus, Theobald.

Eretmopodites condei, Ventrillon, Arch. Parasit. ix, p. 144 (1905).

No males were present, and the few females in Ventrillon's collection were rather rubbed, but the above synonymy, previously suggested by me, is highly probable. 